\title{
MPPT BERDASARKAN ALGORITMA P\&O DAN IC PADA INTERLEAVED-FLYBACK 250W
}

\author{
Y. Munandar Kolewora ${ }^{1}$, Eka Firmansyah ${ }^{2}$, Suharyanto ${ }^{3}$ \\ ${ }^{1,2,3}$ Departemen Teknik Elektro dan Teknologi Informasi \\ Universitas Gadjah Mada \\ Email : munandar.sie14@mail.ugm.ac.id', firmansyah@ugm.ac.id², \\ suharyanto@ugm.ac.id ${ }^{3}$.
}

\begin{abstract}
ABSTRAK
Interleaved-flyback adalah topologi yang lazim digunakan pada inverter mikro dalam aplikasi panel surya. Lazimnya, dalam aplikasi tersebut, diperlukan sebuah algoritma maximum power point tracking (MPPT) untuk meningkatkan perolehan energinya. Dalam tulisan ini, dua algoritma MPPT; perturb \& observe (P\&O) serta incremental conduction (IC) akan diterapkan pada sebuah interleaved-flyback. Dianalisis kemampuan kedua algoritma tersebut untuk menghadapi perubahan intensitas cahaya matahari dalam rentang 600-1000 W/ $\mathrm{m}^{2}$. Dapat disimpulkan di akhir tulisan bahwa algoritma IC menghasilkan energi yang lebih sedikit dari P\&O dengan selisih hanya $0.2 \%$. Sehingga dapat disimpulkan bahwa kedua algoritma tersebut relatif sama dan penerapannya tergantung pada ketersediaan prosesor yang digunakan serta alasan teknis lain.
\end{abstract}

Kata Kunci: MPPT, P\&O, IC, Interleaved-Flyback, Panel Surya.

\begin{abstract}
Interleaved-flyback is a common topology used in micro-inverters in photovoltaic applications. Typically, in the application, a maximum power point tracking algorithm (MPPT) is required to increase its energy gain. In this paper, two MPPT; algorithms perturb \& observe $(P \& O)$ and incremental conduction (IC) will be applied to an interleaved-flyback. Analyzed the ability of both algorithms to face changes in the intensity of sunlight in the range $600-1000 \mathrm{~W} / \mathrm{m}^{2}$. It can be concluded at the end of the paper that the IC algorithm produces less energy than $P \& O$ by a margin of only $0.2 \%$. So it can be concluded that both algorithms are relatively similar and its application depends on the availability of processor used and other technical reasons.
\end{abstract}

Keywords: MPPT, P\&O, IC, Interleaved-Flyback, Photovoltaic. 


\section{PENDAHULUAN}

Energi yang dihasilkan oleh panel surya sangat dipengaruhi oleh kondisi klimatologi seperti iradiasi matahari dan suhu lingkungan sehingga karakteristik arus dan tegangan berubah-ubah (Saidi, 2016). Tegangan keluaran yang rendah dan arus keluaran yang tinggi merupakan ciri dari sumber energi panel surya. Karena karakteristik yang unik dari panel surya tersebut, panel surya tidak dihubungkan secara langsung ke beban tetapi menggunakan sebuah konverter dc/dc untuk menghubungkan antara panel surya dan beban (Kota and Ieee, 2016). Panel surya mempunyai titik daya maksimum (MPP) yang terjadi ketika arus dan tegangan berada pada nilai maksimumnya. Namun, nilai MPP tersebut sangat dipengaruhi oleh iradiasi matahari dan suhu permukaan sel surya (Banu, Beniuga, and Istrate, 2013). Oleh karena itu, telah dikembangkan suatu metode pelacakan yang dapat menyeimbangkan impedansi panel surya dan impedansi beban (impedance matching), sehingga selama nilai tahanan beban sama dengan tahanan dalam pada panel surya, maka daya yang dihasilkan panel surya akan selalu berada pada titik maksimal atau berada dalam kondisi MPP (Hohm and Ropp, 2000). Metode pelacakan tersebut biasa disebut maximum power point tracking (MPPT).

Dalam implementasinya, MPPT terbagi menjadi dua yaitu algoritma dan perangkat kerasnya. Lazimnya, yang menjalankan fungsi MPPT adalah sebuah konverter dc/dc yang terletak di antara panel surya dan beban. Mengendalikan cara kerja konverter tersebut melalui sebuah algoritma tertentu yang memanipulasi gelombang PWM konverter merupakan cara yang umum dilakukan (Guruvulunaidu et al, 2016).

Konverter interleaved-flyback sangat populer pada microinverter karena mampu bekerja pada rentang tegangan yang lebar dan dapat menurunkan riak arus serta mampu bekerja pada frekuensi yang tinggi, sehingga dapat memperkecil ukuran transformator.

Algoritma yang populer dan yang banyak digunakan pada pelacakan sistem panel surya adalah constant voltage, perturb and observe (Mamatha, 2015), 
incremental conductance (Beopjun, 2013), open circuit voltage, short circuit current dan fuzzy logic. Pada metode-metode tersebut membutuhkan pengukuran tegangan, arus atau keduanya dari panel surya.

Tulisan ini mengevaluasi tentang penerapan metode P\&O dan IC pada konverter interleaved-flyback. Di akhir penelitian, diharapkan dapat diperoleh simpulan tentang algoritma mana yang lebih baik untuk diterapkan dalam aplikasi nyata.

\section{METODE PENELITIAN}

Pada Gambar 1, memperlihatkan sistem panel surya. Dimana, terdapat tiga bagian utama yaitu :

1. Panel surya, yang berhubungan langsung dengan cahaya matahari dan mengkonversi cahaya matahari menjadi energi listrik.

2. Konverter interleaved-flyback, berfungsi untuk menaikan atau menurunkan tegangan keluaran dari panel surya agar sesuai dengan tegangan pada beban.

3. Rangkaian kontrol, berupa MPPT, PI dan PWM. Dimana, MPPT merupakan metode pelacakan yang mampu menyerap daya maksimum pada panel surya, PI digunakan untuk mengkoreksi nilai tegangan error sedangkan PWM merupakan pembangkit gelombang untuk memvariasikan duty cycle.

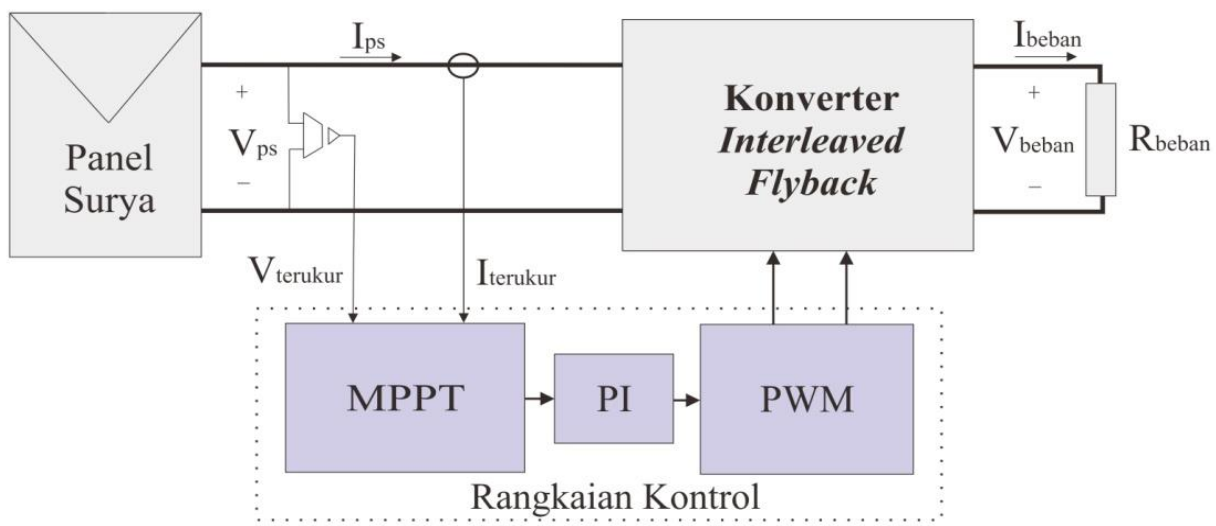

Gambar 1. Sistem panel surya 


\section{Panel Surya}

Sebuah model persamaan rangkaian sederhana untuk sebuah sel surya terdiri dari sebuah dioda yang diparalelkan dengan sebuah sumber arus ideal. Model rangkaian dari sel surya dapat disusun seperti pada Gambar 2.

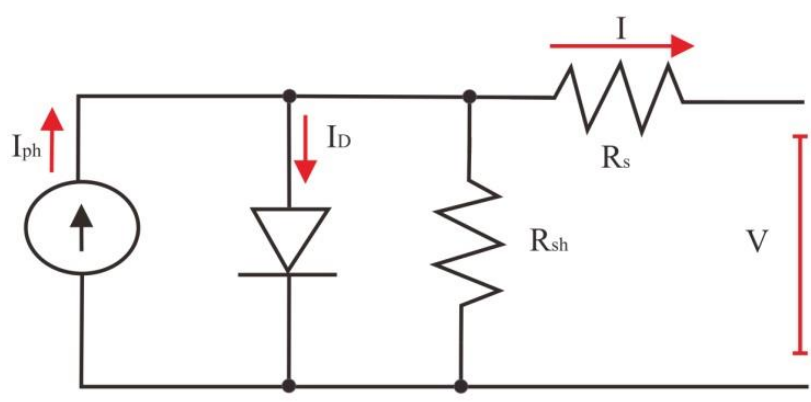

Gambar 2. Rangkaian persamaan sel surya

Persamaan matematik dari rangkaian ekuivalen sel surya pada Gambar 2 dapat dilihat pada persamaan (1).

$$
I=I_{p h}-I_{0}\left[\exp \left(\frac{q\left(V+I R_{s}\right)}{A k T}\right)-1\right]-\frac{V+I R_{s}}{R_{s h}}(1)
$$

Dimana I dan V merupakan arus dan tegangan keluaran dari sel surya, $\mathrm{I}_{\mathrm{ph}}$ adalah arus photo, $\mathrm{I}_{0}$ adalah arus reverse saturation dioda, $\mathrm{q}$ adalah muatan elektron yaitu sebesar $1.602 \times 10^{-19} \mathrm{C}$, A adalah faktor dioda (biasanya antara 1 dan 2), k adalah konstanta Boltzmann yaitu sebesar $1.381 \times 10^{-23} \mathrm{~J} / \mathrm{K}$, T adalah suhu permukaan sel surya, $R_{s}$ adalah tahanan seri dan $R_{\text {sh }}$ adalah tahanan shunt.

\section{Konverter Interleaved-Flyback}

Gambar 3 menunjukan rangkaian utama dari konverter interleavedflyback yang terdiri dari dua buah konverter flyback yang saling bergandengan, dimana setiap phase digeser $180^{\circ}$ pada setiap penyaklaran untuk mencapai persamaan double switching frekuensi yang dapat menurunkan riak arus (Sefa and Özdemir 2009; Xiong and Shen 2016). Kapasitor $\mathrm{C}_{1}$ merupakan kapasitor bulk dan kapasitor $\mathrm{C}_{2}$ merupakan penyimpan energi sementara sebelum ditransfer ke beban, saklar primer $S_{1}$ 
dan $\mathrm{S}_{2}$ adalah saklar utama yang menjalankan fungsi $\mathrm{PWM}$, dioda $\mathrm{D}_{1}$ dan $\mathrm{D}_{2}$ adalah dioda sekunder yang digunakan untuk menghindari rugi dioda reverse dan R merupakan tahanan beban pada konverter interleaved -flyback.

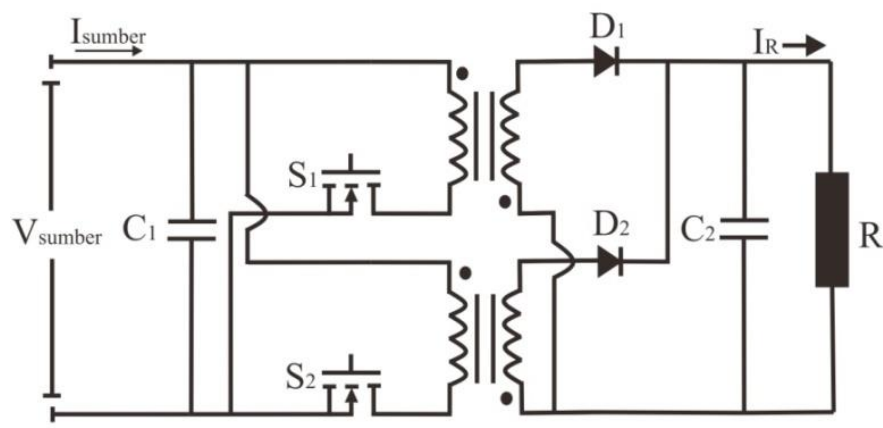

Gambar 3. Rangkaian interleaved flyback

\section{Maximum Power Point Tracking (MPPT)}

MPPT adalah sebuah teknik yang digunakan untuk mencapai titik daya maksimum (MPP) yang dapat diperoleh dari panel surya. Panel surya mempunyai hubungan yang cukup rumit antara iradiasi matahari, suhu lingkungan dan total resistansi yang menghasilkan sebuah karakteristik keluaran arus dan tegangan yang non-linear (Rahman et al. 2016). Sistem MPPT melakukan sampling data tegangan dan arus dari sel surya dan menggunakan sebuah resistans untuk memperoleh keluaran daya maksimum untuk setiap kondisi lingkungan (Bouselham 2009).

a. Perturb and observe $(P \& O)$

metode $\mathrm{P} \& \mathrm{O}$ memulai sistem dengan pemilihan titik kerja dimana duty ratio dari konverter dc/dc akan berubah terhadap waktu. Dengan melakukan pengukuran tegangan dan daya yang melewati panel surya, lalu mengamati apakah terjadi perubahan tegangan dan atau daya sesudah duty ratio diubah. Jika daya meningkat dengan tegangan yang meningkat pula maka duty ratio akan dirubah dengan arah yang sama, jika tidak demikian maka duty ratio akan dirubah pada arah yang berlawanan (Rambo et al. 2014). Adapun algoritma P\&O dapat dilihat pada Gambar 4 dan kurva titik operasi daya-tegangan $(\mathrm{P}-\mathrm{V})$ pada metode $\mathrm{P} \& \mathrm{O}$ dapat dilihat pada Gambar 5. 


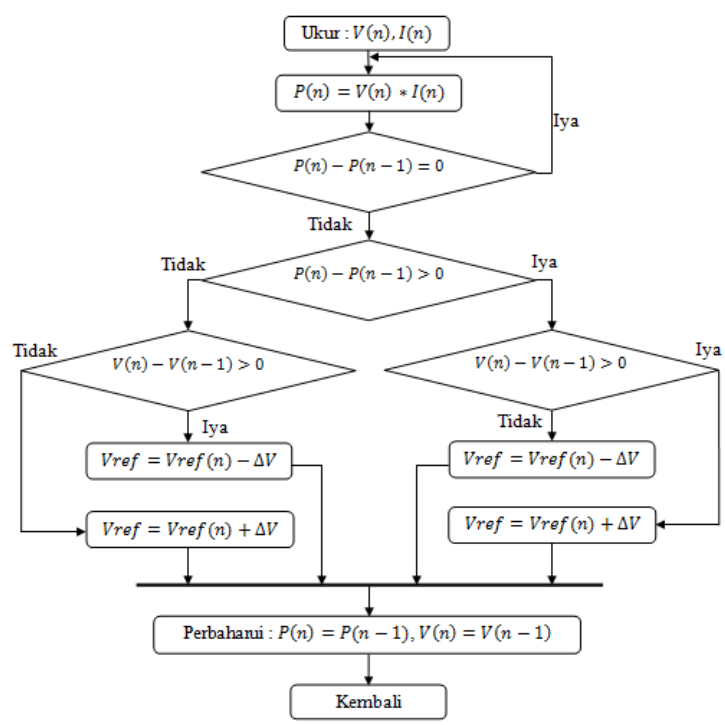

Gambar 4. Algoritma P\&O

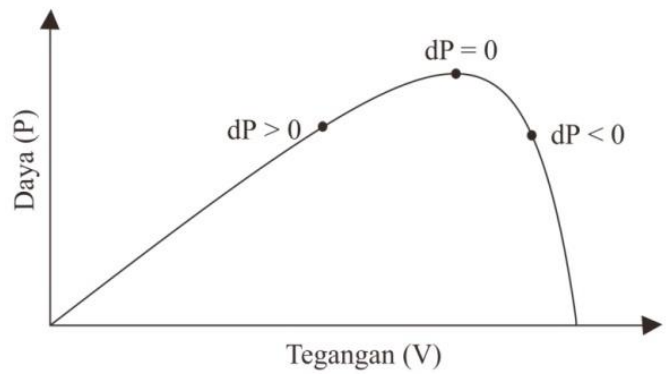

Gambar. 5 Kurva daya-tegangan P\&O

b. Incremental conductance (IC)

Pada algoritma IC konvensional berangkat dari persamaan :

$$
\begin{gathered}
P=V \times I \\
\frac{d P}{d V}=I+V \frac{d I}{d V}
\end{gathered}
$$

Pada titik daya maksimum, persamaan (3) di atas akan sama dengan nol, yang menunjukan puncak titik daya maksimum sehingga persamaannya menjadi :

$$
\left.\frac{d P}{d V}\right|_{M P P}=I+V \frac{d I}{d V}=0
$$

Untuk beberapa level iradiasi pada titik daya maksimum persamannya adalah : 


$$
\frac{d I}{d V}=-\frac{I}{V}
$$

Pada persamaan (5) diatas pada bagian kiri diketahui sebagai incremental conductance dan pada bagian kanan merupakan negatif dari instant conductance. Dengan kata lain bahwa, jika jumlah dari kedua konduktans tersebut adalah nol, maka kondisi tersebut merupakan kondisi titik daya maksimum (MPP) (Huynh and Dunnigan 2016) . Pada Gambar 7 kurva hubungan titik operasi daya-tegangan (P-V) pada metode IC dan Gambar 6 menunjukan algoritma IC.

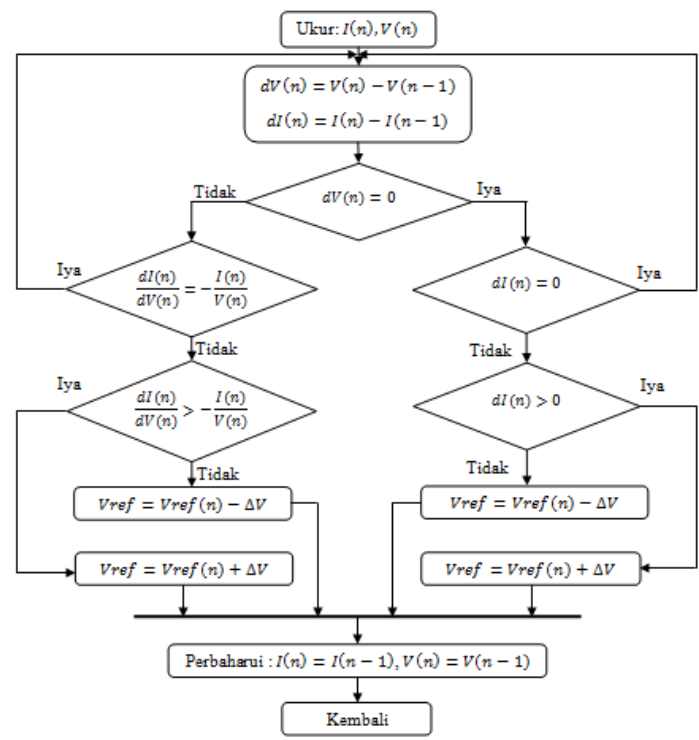

Gambar 6. Algoritma IC

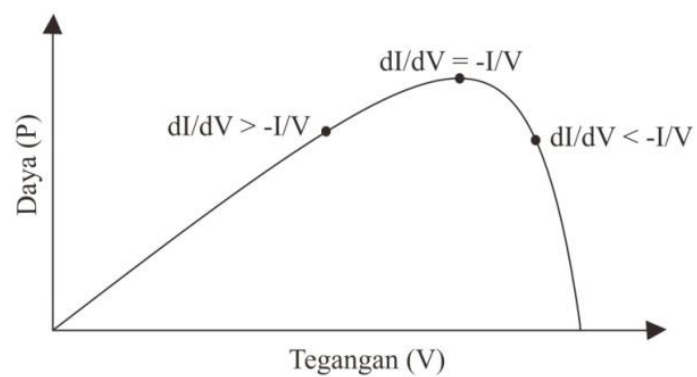

Gambar 7. Kurva daya-tegangan IC

Dari Gambar 7 terlihat tiga kondisi titik operasi yang ditunjukan pada persamaan berikut :

$$
\frac{d I}{d V}=-\frac{I}{V}, \text { Pada MPP }
$$




$$
\begin{gathered}
\frac{d I}{d V}<-\frac{I}{V}, \text { Disisi kanan MPP } \\
\frac{d I}{d V}>-\frac{I}{V}, \text { Disisi kiri MPP }
\end{gathered}
$$

\section{PERANCANGAN DAN PENGUJIAN}

Bagian ini membahas perancangan keseluruhan sistem panel surya yang digunakan pada penelitian. Dimana, pada perancangan digunakan simulator PSIM.

\section{Perancangan Iradiasi Matahari}

Untuk melakukan pengujian sistem panel surya pada perubahan iradiasi matahari, dibuat pemodelan perubahan iradiasi matahari seperti yang ditunjukan pada Gambar 8. Rentang iradiasi yang akan diteliti adalah antara 600 sampai dengan $1000 \mathrm{~W} / \mathrm{m}^{2}$.

Angka ini dipilih karena menunjukan nilai iradiasi matahari pada saat pukul 09.00-12.00 atau 12.00-15.00 (Hasyim Asy'ari1, Jatmiko2 2013). Dari setiap perubahan iradiasi matahari yang terjadi, telah ditentukan waktu perubahannya yaitu selama $0,05 \mathrm{~s}$. Waktu perubahan ini dipilih karena selama waktu tersebut sistem sudah berada pada kondisi steady state.

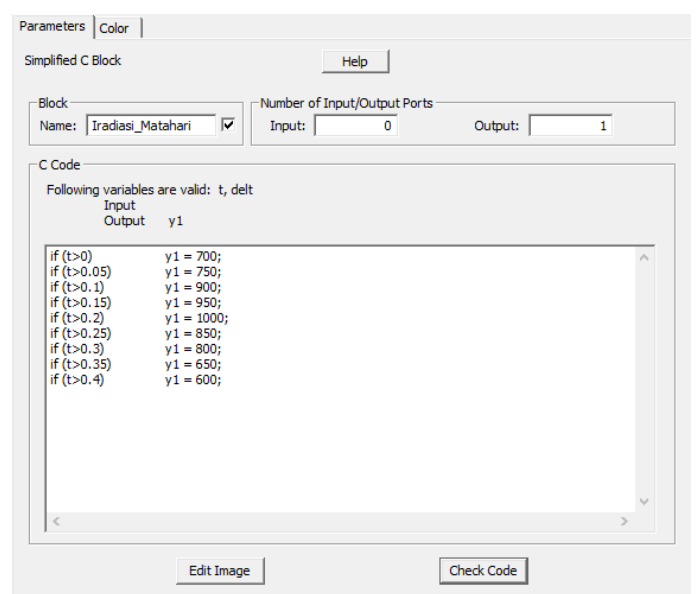

Gambar 8. Model perubahan iradiasi matahari 


\section{Perancangan Panel Surya}

Model panel surya yang digunakan dalam tulisan ini diambil dari spesifikasi produk solar world dengan tipe sunmodule SW 250 mono / Version 2.0 and 2.5 frame seperti yang terlihat pada Tabel 1.

Tabel 1. Spesifikasi Panel Surya

\begin{tabular}{|l|c|}
\hline \multicolumn{2}{|l|}{ Spesifikasi @ $S=1000 \mathrm{~W} / \mathrm{m}^{2}$ pada $T=27^{\circ} \mathrm{C}$} \\
\hline Daya maksimum, $P_{m p p}$ & $250 \mathrm{~W}$ \\
\hline Tegangan maksimum, $V_{m p p}$ & $31.1 \mathrm{~V}$ \\
\hline Arus maksimum, $I_{m p p}$ & $8.05 \mathrm{~A}$ \\
\hline Tegangan open circuit, $V_{o c}$ & $37.8 \mathrm{~V}$ \\
\hline Arus short circuit, $I_{s c}$ & $8.28 \mathrm{~A}$ \\
\hline \multicolumn{2}{|c|}{ Karakteristik suhu } \\
\hline Koefisien suhu dari $I_{s c}$ & $0.004 \% / \mathrm{K}$ \\
\hline Koefisien suhu dari $V_{o c}$ & $-0.30 \% / \mathrm{K}$ \\
\hline
\end{tabular}

Dari spesifikasi Tabel 1 diatas, dibuat perancangan sistem panel surya seperti yang terlihat pada Gambar 9. Dimana, dari pemodelan panel surya yang dilakukan telah diperoleh; $\mathrm{P}_{\max }=250.16 \mathrm{~W}, \mathrm{~V}_{\max }=32 \mathrm{~V}$ dan $\mathrm{I}_{\max }=7.82 \mathrm{~A}$.

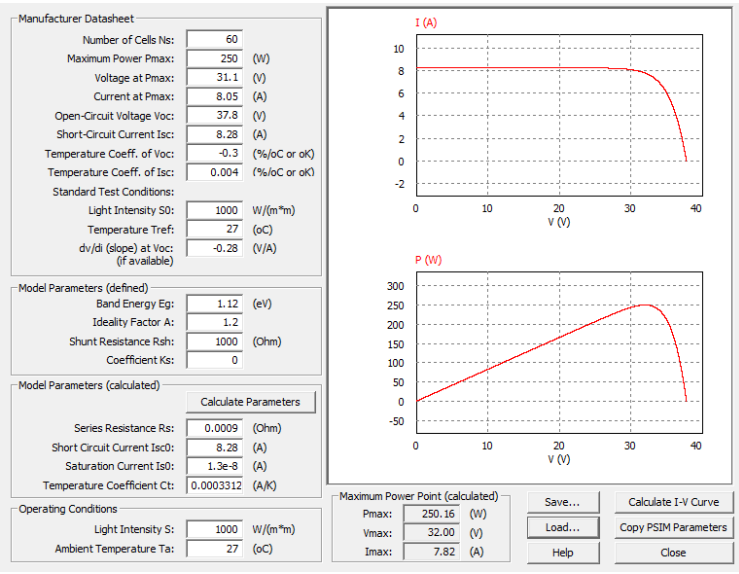

Gambar 9. Perancangan panel surya sunmodule SW $250 \mathrm{~W}$

Untuk hasil pengukuran panel surya sunmodul SW $250 \mathrm{~W}$ pada perubahan iradiasi matahari dari $600 \mathrm{~W} / \mathrm{m}^{2}$ sampai $1000 \mathrm{~W} / \mathrm{m}^{2}$ diperoleh kurva arus-tegangan (I-V) seperti yang ditinjukan pada Gambar 10 dan kurva daya-tegangan (P-V) seperti yang ditunjukan pada Gambar 11. 


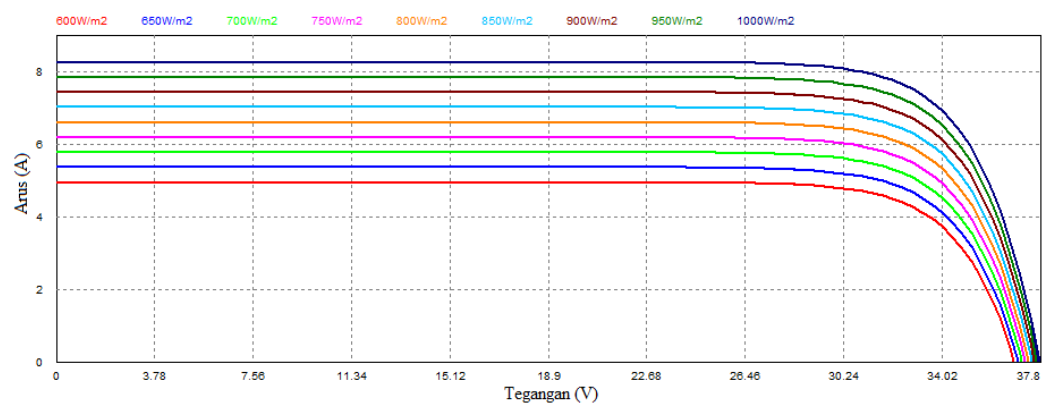

Gambar 10. Kurva I-V panel surya 250W

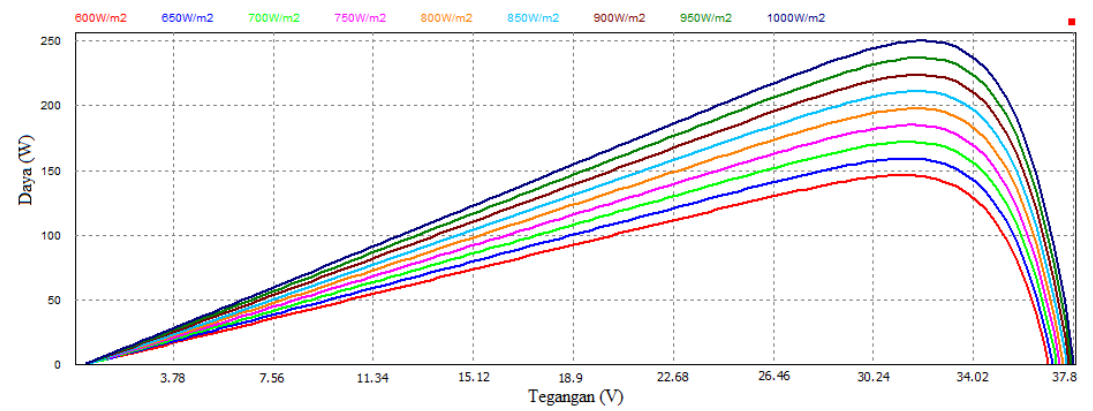

Gambar 11. Kurva P-V panel surya 250W

\section{Perancangan konverter Interleaved-Flyback}

Dengan tegangan input terendah yang dihasilkan oleh panel surya sebesar $32 \mathrm{~V}_{\mathrm{dc}}$, untuk menghasilkan tegangan keluaran sebesar $400 \mathrm{~V}_{\mathrm{dc}}$ yang diperlukan untuk menghasilkan luaran $220 \mathrm{~V}_{\mathrm{ac}}$, diperlukan transformator dengan rasio tegangan sebesar 2:25. Paramerter konverter interleaved flyback yang digunakan yaitu terdapat pada Tabel 2.

\begin{tabular}{|} 
Tabel 2. Parameter Flyback Interleaved \\
\begin{tabular}{|l|c|}
\hline \multicolumn{2}{|c|}{ Parameter sistem flyback interleaved } \\
\hline Kapasitor masukan, $\mathrm{C}_{1}$ & $500 \mu \mathrm{F}$ \\
\hline Kapasitor keluaran, $\mathrm{C}_{2}$ & $5 \mu \mathrm{F}$ \\
\hline Tahanan keluaran, $\mathrm{R}_{\mathrm{L}}$ & $640 \Omega$ \\
\hline Frekuensi @ switching $\mathrm{S}_{1}, \mathrm{~S}_{2}$ & $100 \mathrm{kHz}$ \\
\hline
\end{tabular}
\end{tabular}

Gambar 12 memperlihatkan perancangan konverter interleaved-flyback. Dimana, tegangan masukan $\left(\mathrm{V}_{\text {in }}\right)$ yang terbaca sebesar $32 \mathrm{~V}_{\mathrm{dc}}$, tegangan keluaran $\left(\mathrm{V}_{\text {out }}\right)$ sebesar $400 \mathrm{~V}_{\mathrm{dc}}$, arus masukan $\left(\mathrm{I}_{\text {in }}\right)$ sebesar $7.82 \mathrm{~A}$ dan arus keluaran ( $\mathrm{I}_{\text {out }}$ ) sebesar 0.625 A. Adapun kurva arus dan tegangan pada interleaved-flyback ditunjukan pada Gambar 13. 


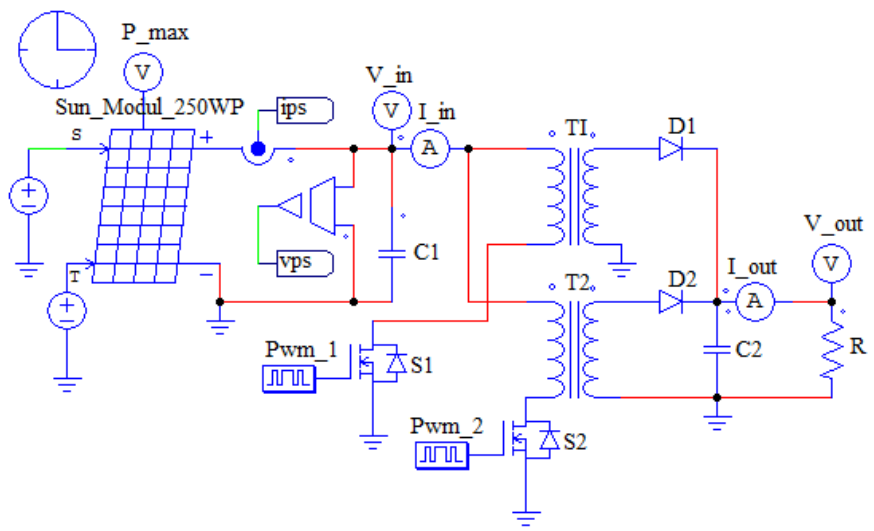

Gambar 12. Perancangan konverter interleaved-flyback
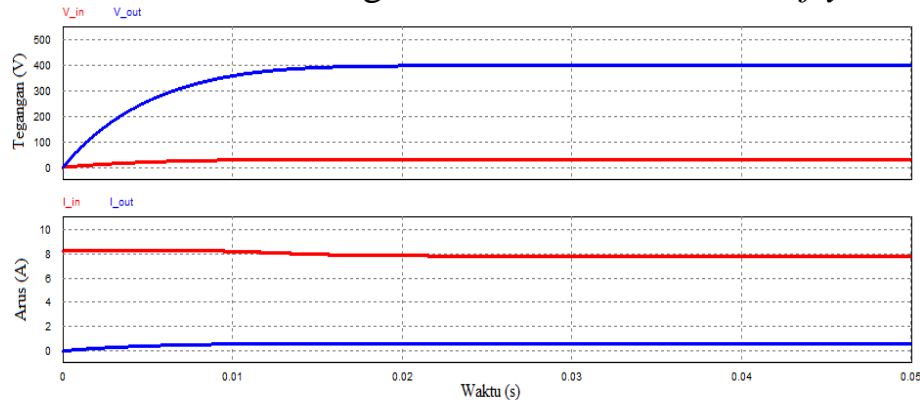

Gambar 13. Kurva tegangan dan arus konverter

\section{Perancangan Maximum Power Point Tracking (MPPT)}

\section{a. Perturb and Observe $(P \& O)$}

Model kontrol strategi dari algoritma PO dapat dilihat pada Gambar 14. Sistem akan membaca tegangan $\left(\mathrm{V}_{\mathrm{ps}}\right)$ dan arus $\left(\mathrm{I}_{\mathrm{ps}}\right)$ dari panel surya dengan menggunakan sensor tegangan dan arus lalu menghitung perubahan daya dan tegangan yang diperoleh dengan menggunakan differentiator (sT). Untuk memudahkan pengamatan sistem telah dibuat dua kondisi. Kondisi pertama, Ketika perubahan daya mengalami peningkatan $\mathrm{P}_{(\mathrm{n})}>\mathrm{P}_{(\mathrm{n}-1)}$ dengan tegangan yang meningkat pula $\mathrm{V}_{(\mathrm{n})}>\mathrm{V}_{(\mathrm{n}-1)}$ maka tegangan referensi $\left(\mathrm{V}_{\text {ref }}\right)$ akan ditambah dengan step tegangan $(\Delta \mathrm{V})$ sebesar 0,1 dan ketika kondisi tegangan turun $\mathrm{V}_{(\mathrm{n})}<\mathrm{V}_{(\mathrm{n}-1)}$ maka $\mathrm{V}_{\text {ref }}$ dikurangi $\Delta \mathrm{V}$ sebesar 0,1 . Kondisi kedua, ketika perubahan daya mengalami penurunan $\mathrm{P}_{(\mathrm{n})}<\mathrm{P}_{(\mathrm{n}-1)}$ dengan tegangan yang meningkat $\mathrm{V}_{(\mathrm{n})}>\mathrm{V}_{(\mathrm{n}-1)}$ maka $\mathrm{V}_{\text {ref }}$ ditambah $\Delta \mathrm{V}$ sebesar 0,1 dan ketika tegangan turun $\mathrm{V}_{(\mathrm{n})}<\mathrm{V}_{(\mathrm{n}-1)}$ maka $\mathrm{V}_{\text {ref }}$ dikurangi $\Delta \mathrm{V}$ sebesar 0,1 . Kemudian menghitung selisih dari tegangan yang terbaca dari panel surya $\left(\mathrm{V}_{\mathrm{ps}}\right)$ dengan tegangan 
referensi $\left(\mathrm{V}_{\text {ref }}\right)$ yang sudah terakumulasi oleh step tegangan $(\Delta \mathrm{V})$ dan hasil dari selisih tegangannya disebut tegangan error. Kemudian data tegangan error akan diolah di PI.

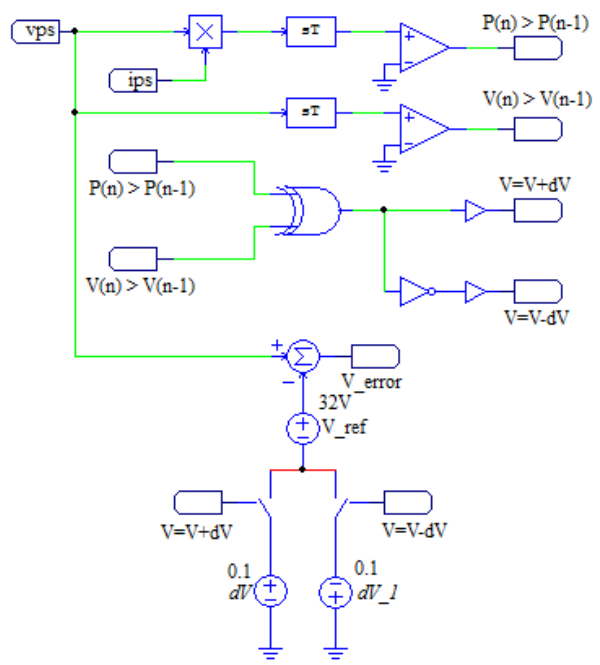

Gambar 14. Model kontrol strategi P\&O

b. Incremental Conductance (IC)

Model kontrol strategi dari algoritma IC dapat dilihat pada Gambar 15. Sistem akan membaca tegangan $\left(\mathrm{V}_{\mathrm{ps}}\right)$ dan arus $\left(\mathrm{I}_{\mathrm{ps}}\right)$ dari panel surya lalu menghitung perubahan tegangan dan arus yang diperoleh dengan menggunakan differentiator (sT). Untuk memudahkan pengamatan sistem telah dibuat dua kondisi. Kondisi pertama, Ketika perubahan tegangan sama dengan nol $(\mathrm{dv}=0)$ dengan perubahan arus yang meningkat $(\mathrm{di}>0)$ maka tegangan referensi $\mathrm{V}_{\text {ref }}$ ditambah step tegangan $(\Delta \mathrm{V})$ sebesar 0,1 dan ketika kondisi arus menurun $(\mathrm{di}<0)$ turun maka $\mathrm{V}_{\text {ref }}$ dikurangi $\Delta \mathrm{V}$ sebesar 0,1. Kondisi kedua, ketika perubahan tegangan tidak sama dengan nol $(\mathrm{dv} !=0)$ dengan nilai incremental conductance (di/dv) lebih besar dari negatif instant conductance (i/v) maka $\mathrm{V}_{\text {ref }}$ di tambah $\Delta \mathrm{V}$ sebesar 0,1 dan ketika nilai di/dv lebih kecil dari negatif $\mathrm{i} / \mathrm{v}$ maka $\mathrm{V}_{\text {ref }}$ dikurangi $\Delta \mathrm{V}$ sebesar 0,1. Kemudian hasil perhitungan dari tegangan yang terbaca dari panel surya $\left(\mathrm{V}_{\mathrm{ps}}\right)$ dan tegangan referensi $\left(\mathrm{V}_{\mathrm{ref}}\right)$ yang sudah terakumulasi oleh step tegangan $(\Delta \mathrm{V})$ akan diolah di PI. 


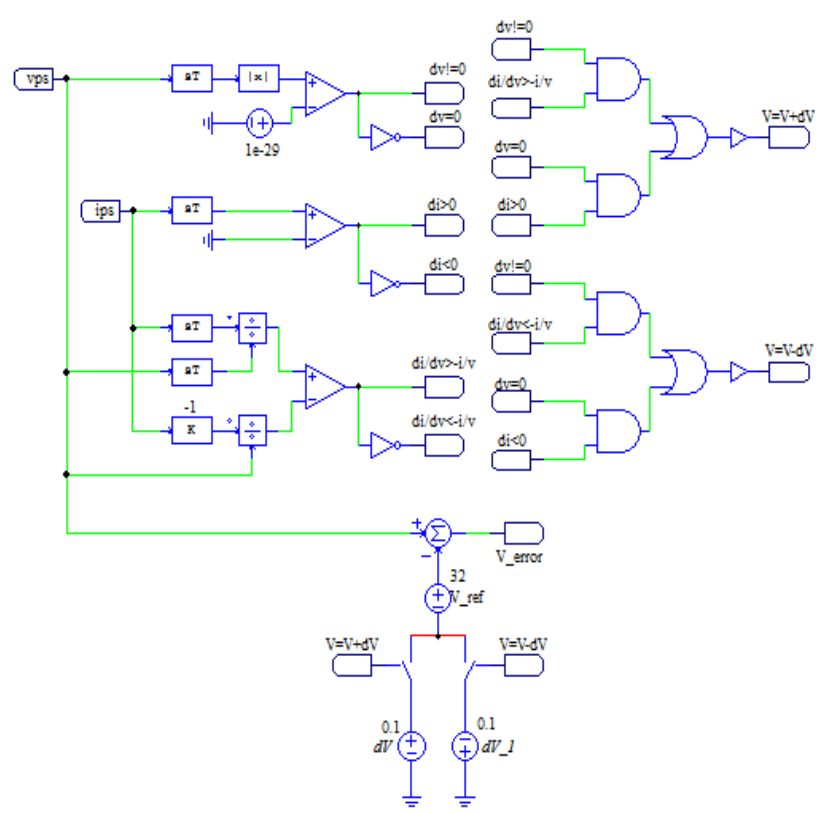

Gambar 15. Model kontrol strategi IC

\section{Kontrol PI}

Kontrol PI digunakan untuk mengkoreksi nilai tegangan error dari MPPT. Untuk penentuan tuning PI digunakan persamaan berikut :

$$
\begin{gathered}
V_{m}(t)=K_{P} V_{E}(t)+\frac{K_{P}}{T_{i}} \int V_{E}(t) d t \\
V_{E}=V_{r e f}-V_{p s} \quad(10) \\
G(s)=\frac{K_{P}\left(1+s T_{i}\right)}{s T_{i}} \quad(11)
\end{gathered}
$$

$\mathrm{V}_{\mathrm{m}}$ merupakan tegangan koreksi yang merupakan keluaran dari kotrol PI. Dengan gain $\mathrm{K}_{\mathrm{p}}$ sebesar 0,2 dan time constant $\mathrm{T}_{\mathrm{i}}$ sebesar 0,35 dan kemudian diteruskan ke limiter untuk membatasi $\mathrm{V}_{\mathrm{m}}$ tidak boleh lebih dari $+5 \mathrm{~V}$ atau 5V. Setelah itu, tegangan koreksi $\left(\mathrm{V}_{\mathrm{m}}\right)$ akan di teruskan ke PWM.

\section{Perancangan Pulse Width Modulation (PWM)}

PWM digunakan sebagai pembangkit gelombang untuk memvariasikan duty cycle. Karena konverter yang digunakan adalah interleaved flyback maka PWM yang digunakan harus disesuaikan dengan jumlah saklar konverter 
tersebut yaitu 2 buah, dimana gelombang penyaklarannya digeser $180^{\circ}$ untuk pengoperasian PWM, nilai tegangan error $\left(\mathrm{V}_{\text {error }}\right)$ dari MPPT akan dibandingkan dengan nilai tegangan triangular atau gelombang segitiga dengan menggunakan komparator. Hasil perbandingan tegangan error dan tegangan triangular tersebut adalah duty cycle yang menentukan waktu on dan waktu off dari saklar konverter. Adapun model perancangan pada PWM ditunjukan pada Gambar 16.

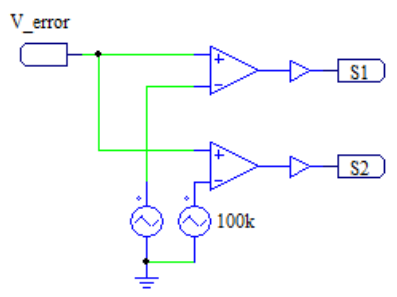

Gambar 16. Model PWM

Untuk penentuan nilai gelombang segitiga atau nilai tegangan triangular disesuaikan dengan nilai batas tegangan error yaitu dari $-5 \mathrm{~V}$ sampai $+5 \mathrm{~V}$ dan digunakan frekuensi penyaklaran sebesar $100 \mathrm{kHz}$. Adapun parameter yang digunakan pada PWM ditunjukan pada Gambar 17 dan hasil uji PWM dapat dilihat pada Gambar 18.

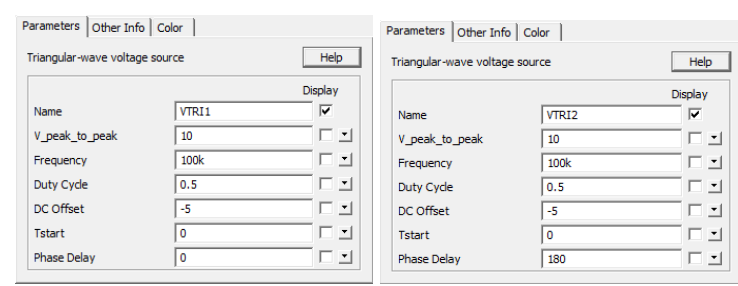

Gambar 17. Paramerter PWM 1 dan 2
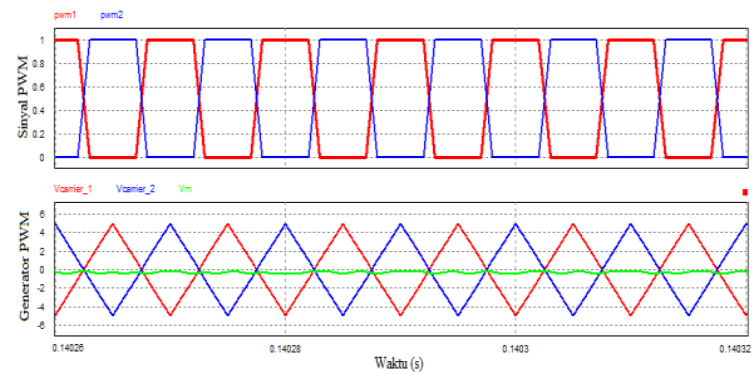

Gambar 18. sinyal keluaran PWM 


\section{HASIL DAN PEMBAHASAN}

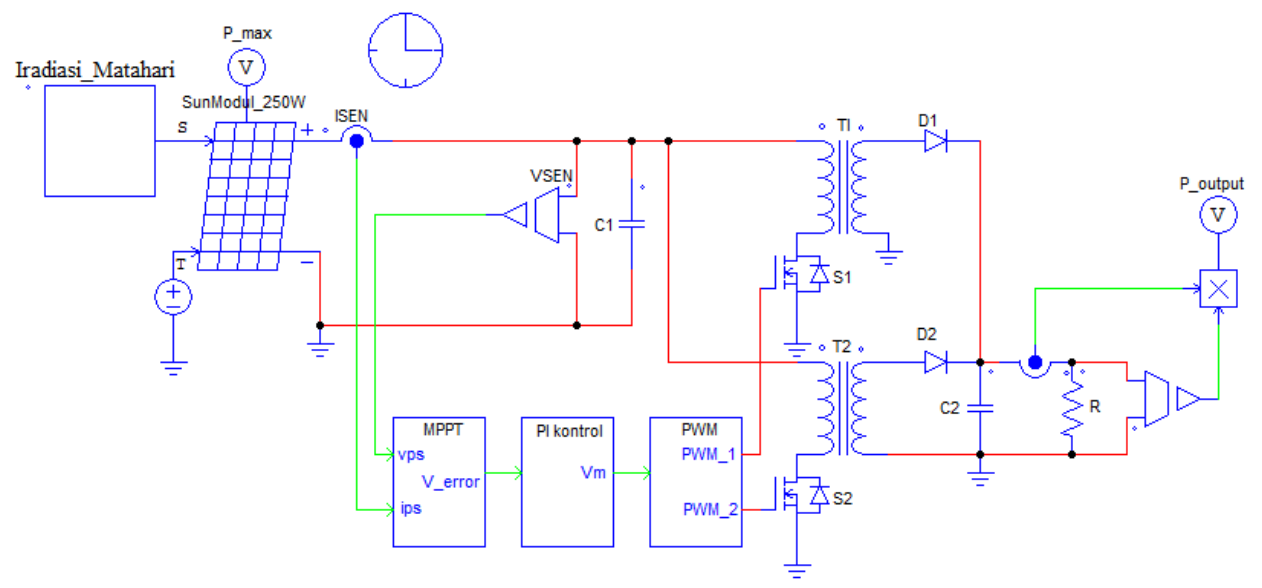

Gambar 19. Sistem Panel surya $250 \mathrm{~W}$

Simulasi dilakukan dengan menghitung nilai efisiensi MPPT digunakan persamaan (12).

$$
\eta_{M P P T}=\frac{\int_{0}^{T} P_{\text {out_max }}(t) d t}{\int_{0}^{T} P_{\max }(t) d t} \times 100 \%
$$

Dimana $\mathrm{P}_{\text {out_max }}(\mathrm{t})$ adalah daya yang diperoleh dari panel surya dibawah kondisi MPPT, dan $\mathrm{P}_{\max }(\mathrm{t})$ adalah daya maksimum ideal dari panel surya, dan $\mathrm{T}$ merupakan periode waktu untuk setiap perubahan iradiasi. Adapun rangkaian pengujian sistem panel surya $250 \mathrm{~W}$ ditunjukan pada Gambar 19. Hasil simulasi dari sistem panel surya berdasarkan metode P\&O dapat dilihat pada Gambar 20 dan metode IC dapat dilihat pada Gambar 21. Pada gambar masing-masing metode MPPT tersebut diperoleh nilai daya keluaran minimum ( $\left.\mathrm{P}_{\text {out_min }}\right)$ yang menunjukan nilai daya keluaran sistem panel surya ketika tanpa menggunakan MPPT dan nilai daya keluaran maksimum $\left(\mathrm{P}_{\text {out_max }}\right)$ yang menunjukan nilai daya dari MPPT yang memaksakan konverter interleaved flyback untuk bekerja mendekati nilai daya maksimum panel surya $\left(\mathrm{P}_{\max }\right)$ sehingga beban dapat menyerap atau bekerja di titik daya maksimum (MPP).

Pada Tabel 3 diperoleh nilai daya maksimum pada panel surya $\left(\mathrm{P}_{\max }\right)$, nilai daya keluaran maksimum yang diserap oleh beban berdasarkan metode $\mathrm{P} \& \mathrm{O}$ 
( $\mathrm{P}_{\text {out_max_PO}}$ ), dan nilai daya keluaran maksimum yang diserap oleh beban berdasarkan metode IC (Pout_max_IC) dari masing-masing perubahan iradiasi matahari pada periode yang telah ditentukan.

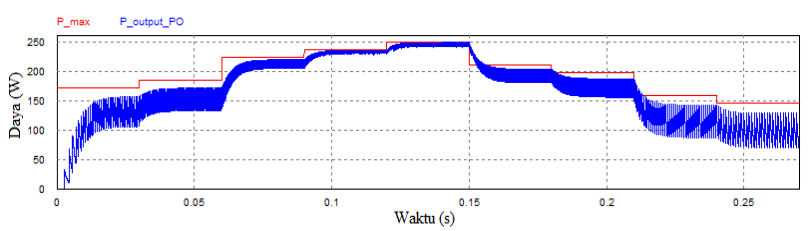

Gambar 20. Kurva daya keluaran P\&O

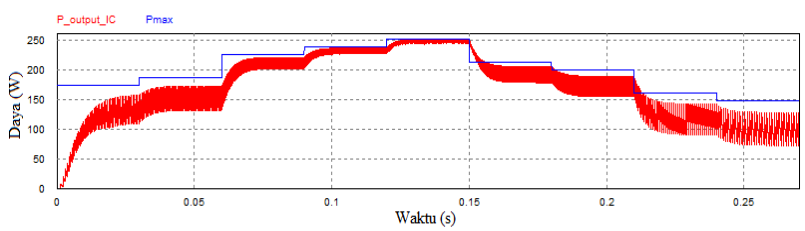

Gambar 21. Kurva daya keluaran IC

Tabel 3. Daya Keluaran Maksimum

\begin{tabular}{|c|c|c|c|c|c|c|}
\hline \multicolumn{3}{|c|}{$\begin{array}{l}\text { Periode } \\
(s)\end{array}$} & $\begin{array}{c}\text { Iradiasi } \\
\left(\mathrm{W} / \mathrm{m}^{2}\right)\end{array}$ & $\begin{array}{l}P_{\max } \\
(W)\end{array}$ & $\begin{array}{c}P_{\text {out_max_PO }} \text { (W) } \\
(W)\end{array}$ & $\begin{array}{c}P_{\text {out_max_IC }} \\
(W)\end{array}$ \\
\hline 0 & - & 0,05 & 700 & 172,15 & 167,84 & 167,35 \\
\hline 0,05 & - & 0,1 & 750 & 185,08 & 181,24 & 180,77 \\
\hline 0,1 & - & 0,15 & 900 & 224,05 & 222,98 & 222,83 \\
\hline 0,15 & - & 0,2 & 950 & 237,09 & 236,78 & 236,71 \\
\hline 0,2 & - & 0,25 & 1000 & 250,15 & 250,11 & 250,13 \\
\hline 0,25 & - & 0,3 & 850 & 211,03 & 209,08 & 208,93 \\
\hline 0,3 & - & 0,35 & 800 & 198,04 & 195,06 & 194,64 \\
\hline 0,35 & - & 0,4 & 650 & 159,26 & 154,79 & 154,32 \\
\hline 0,4 & - & 0,45 & 600 & 146,41 & 142,11 & 141,75 \\
\hline
\end{tabular}

Dengan menggunakan rumus dari persamaan (12), maka diperoleh nilai efisiensi

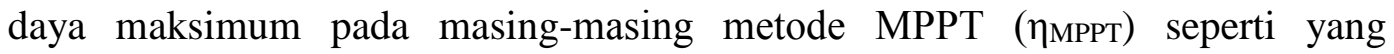
ditunjukan pada Tabel 4. Dimana, nilai rerata efisiensi pada metode P\&O ( $\left.\eta_{\mathrm{P} \& O}\right)$ sebesar 98,51\% dan nilai rerata efisiensi pada metode IC ( $\eta_{\text {IC }}$ ) sebesar 98,35\% dari keseluruhan perubahan iradiasi matahari.

Mengacu pada Tabel 4, maka dibuat grafik nilai efisiensi MPPT (\%) terhadap periode iradiasi matahari (s) yang menunjukan perubahan iradiasi matahari seperti yang ditunjukan pada Gambar 22. Pada grafik tersebut menunjukan kinerja yang baik dari metode $\mathrm{P} \& \mathrm{O}$ dan IC pada periode iradiasi 
matahari antara $0,1 \mathrm{~s}-0,3 \mathrm{~s}$ yang menunjukan iradiasi matahari diatas $850 \mathrm{~W} / \mathrm{m}^{2}$ dimana efisiensi MPPT diatas $99 \%$ dan pada periode iradiasi matahari dari 0s-0,1s dan $0,3 \mathrm{~s}-0,45 \mathrm{~s}$ yang menunjukan iradiasi matahari dibawah $850 \mathrm{~W} / \mathrm{m}^{2}$ dimana efisiensi MPPT berkisar 96\% - 99\%.

Tabel 4. Daya Efisiensi Keluaran Maksimum

\begin{tabular}{|lll|l|c|c|}
\hline \multicolumn{2}{|c|}{$\begin{array}{c}\text { Periode } \\
(s)\end{array}$} & $\begin{array}{c}\text { Iradiasi } \\
\left({\left.\mathrm{W} / \mathrm{m}^{2}\right)}^{2}\right.\end{array}$ & $\begin{array}{c}\eta_{P \& O} \\
(\%)\end{array}$ & $\begin{array}{c}\eta_{I C} \\
(\%)\end{array}$ \\
\hline 0 & - & 0,05 & 700 & 97,49 & 97,21 \\
\hline 0,05 & - & 0,1 & 750 & 97,92 & 97,67 \\
\hline 0,1 & - & 0,15 & 900 & 99,52 & 99,45 \\
\hline 0,15 & - & 0,2 & 950 & 99,86 & 99,83 \\
\hline 0,2 & - & 0,25 & 1000 & 99,98 & 99,99 \\
\hline 0,25 & - & 0,3 & 850 & 99,07 & 99,01 \\
\hline 0,3 & - & 0,35 & 800 & 98,49 & 98,28 \\
\hline 0,35 & - & 0,4 & 650 & 97,19 & 96,89 \\
\hline 0,4 & - & 0,45 & 600 & 97,06 & 96,81 \\
\hline Rerata $\boldsymbol{\eta}$ & & $\mathbf{9 8 , 5 1}$ & $\mathbf{9 8 , 3 5}$ \\
\hline
\end{tabular}

Metode $\mathrm{P} \& \mathrm{O}$ menunjukan kinerja yang lebih baik pada iradiasi dibawah 850 $\mathrm{W} / \mathrm{m}^{2}$ karena metode $\mathrm{P} \& \mathrm{O}$ tersusun dari rangkaian yang lebih sederhana sehingga rugi-ruginya lebih kecil dibandingkan dengan rangkaian pada metode IC.

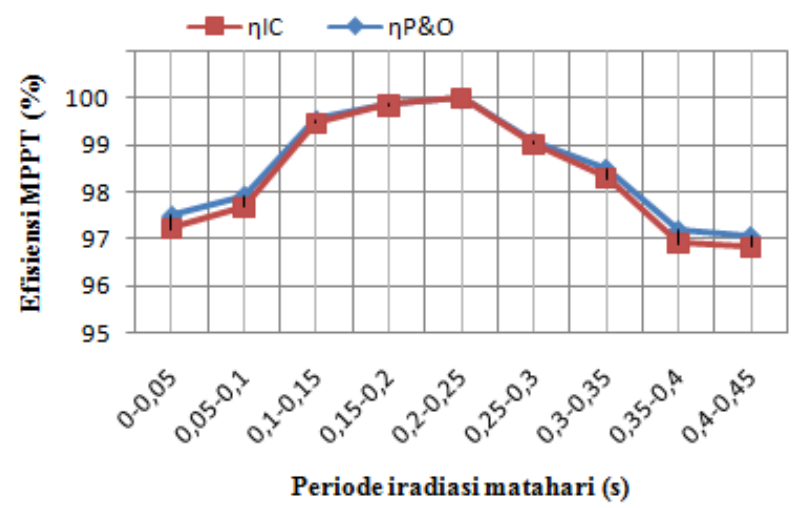

Gambar 22. Grafik efisiensi MPPT terhadap periode iradiasi matahari

\section{KESIMPULAN DAN SARAN}

Pada makalah ini telah dipaparkan perancangan keseluruhan sistem panel surya $250 \mathrm{~W}$ untuk membandingkan kinerja maximum power point tracking (MPPT) pada metode perturb and observe $(\mathrm{P} \& \mathrm{O})$ dan incremental conductance (IC) dengan menggunakan simulator PSIM. Panel surya yang digunakan pada 
penelitian ini yaitu Sunmodule $S W 250 \mathrm{~W}$ dengan spesifikasi $\mathrm{V}_{\max }=32 \mathrm{~V}_{\mathrm{dc}}$ dan $\mathrm{I}_{\max }=7,82$ A. Digunakan konverter interleaved flyback dengan tegangan keluaran ( $\mathrm{V}_{\text {out }}$ ) mencapai $400 \mathrm{~V}_{\mathrm{dc}}$ dan arus output sebesar $0.625 \mathrm{~A}$.

Pada pengujian MPPT digunakan kondisi iradiasi matahari yang berubah-ubah dari $600 \mathrm{~W} / \mathrm{m}^{2}$ sampai $1000 \mathrm{~W} / \mathrm{m}^{2}$ pada periode waktu yang telah ditentukan yaitu selama $0,05 \mathrm{~s}$.

Hasil simulasi diperoleh nilai daya keluaran maksimum $\left(\mathrm{P}_{\text {out_max }}\right)$ yang mampu diserap dari panel surya $\left(\mathrm{P}_{\max }\right)$ pada masing-masing metode MPPT. Hasil simulasi menunjukan metode $\mathrm{P} \& \mathrm{O}$ memiliki efisiensi yang lebih baik dibandingkan dengan metode IC, dimana nilai rerata efisiensi MPPT pada metode P\&O ( $\left.\eta_{\mathrm{PO}}\right)$ sebesar 98,51\% dan nilai rerata efisiensi MPPT pada metode IC ( $\left.\eta_{\text {IC }}\right)$ sebesar $98,35 \%$.

Saran penelitian selanjutnya adalah di harapkan untuk dibuat hardware MPPT yang dapat diimplementasikan pada microinverter.

\section{DAFTAR PUSTAKA}

Banu, Ioan Viorel, Razvan Beniuga, and Marcel Istrate. 2013. "Comparative Analysis of the Perturb-and-Observe and Incremental Conductance MPPT Methods." In 2013 - 8th International Symposium on Advanced Topics in Electrical Engineering, ATEE 2013, , 23-26.

Beopjun, Jeon et al. 2013. "IncCond MPPT Control Using Flyback Converter." IEEE: $357-61$.

Bouselham, L. 2009. "Comparative Study of Different MPPT Methods for Photovoltaic System.” IEEE 32.

Guruvulunaidu, P, S S Biswas, Ch Saibabu, and S Satyanarayana. 2016. "Modeling of Interleaved Fly-Back Converter for Photo Voltaic Applications Using PSIM." AIJRSTEM 16-253: 181-86.

Hasyim Asy'ari1, Jatmiko2, Angga3. 2013. "INTENSITAS CAHAYA MATAHARI TERHADAP DAYA KELUARAN PANEL SEL SURYA." Simposium Nasional RAPI XI FT UMS - 2012: 52-57.

Hohm, D P, and M E Ropp. 2000. "Comparative Study of Maximum Power Point Tracking Algorithms Using an Experimental, Programmable, Maximum Power Point Tracking Test Bed." Photovoltaic Specialists Conference, 2000. Conference Record of the Twenty-Eighth IEEE: 1699-1702. 
Huynh, Duy C, and Matthew W Dunnigan. 2016. "Development and Comparison of an Improved Incremental Conductance Algorithm for Tracking the MPP of a Solar PV Panel." IEEE Transactions on Sustainable Energy 7(4): 142129.

Kota, Venkata Reddy, and Member Ieee. 2016. "A Simple and Efficient MPPT Scheme for PV Module Using 2-Dimensional Lookup Table.” IEEE: 2-8.

Mamatha, Gangavarapu. 2015. "Perturb and Observe MPPT Algorithm Implementation for PV Applications." IJCSIT 6(2): 1884-87.

Morales-Acevedo, Arturo, Jose Luis Diaz-Bernabe, and Ruben GarridoMoctezuma. 2014. "Improved MPPT Adaptive Incremental Conductance Algorithm." In IECON Proceedings (Industrial Electronics Conference), , $5540-45$.

Nedumgatt, Jacob James et al. 2011. "Perturb and Observe MPPT Algorithm for Solar PV Systems-Modeling and Simulation." In Proceedings - 2011 Annual IEEE India Conference: Engineering Sustainable Solutions, INDICON2011 ,

Rahman, Md Wazedur, Chaitanya Bathina, V Karthikeyan, and R. Prasanth. 2016. "Comparative Analysis of Developed Incremental Conductance (IC) and Perturb \& Observe (P\&O) MPPT Algorithm for Photovoltaic Applications." In Proceedings of the 10th International Conference on Intelligent Systems and Control, ISCO 2016,.

Rambo, Carlos E B, Fernando B Reis, Guilherme R Pedrollo, and Fernando S Reis. 2014. "Improving Performance of the P \& O MPPT Using Derivative of Photovoltaic Panel Voltage." IEEE.

Saidi, Ahmed. 2016. "Comparison of IC and P \& O Algorith Algorithms Ms in MPPT for Grid Connected PV Module.” IEEE: 213-18.

Sefa, Ibrahim, and Şaban, Özdemir. 2009. "Experimental Study of Interleaved MPPT Converter for PV Systems." In IECON Proceedings (Industrial Electronics Conference), , 456-61.

Xiong, Xiong, and Anwen Shen. 2016. "Improved Maximum Power Point Tracking in PV System Based on Flyback Converter." In Proceedings - 2015 Chinese Automation Congress, CAC 2015, 1211-14. 